\title{
Chemical Constituents from Euphorbia kansui
}

\author{
Qiao Zhang ${ }^{1}$, Qin-Rong Zhou ${ }^{1}$, Jian-Wei Lou ${ }^{1}$, Pei-Dong Chen ${ }^{1}$, Wei-Feng Yao ${ }^{1}$, Wei-Wei Tao ${ }^{1}$, \\ Yu-Ping Tang ${ }^{2}$, Guan-Cheng Dai ${ }^{1}$, Kun Wang ${ }^{1}$ and Li Zhang ${ }^{1, *}$ \\ 1 Jiangsu Key Laboratory for High Technology Research of TCM Formulae, National and Local Collaborative \\ Engineering Center of Chinese Medicinal Resources Industrialization and Formulae Innovative Medicine \\ and Jiangsu Collaborative Innovation Center of Chinese Medicinal Resources Industrialization, \\ Nanjing University of Chinese Medicine, Nanjing 210023, China; 18700081184@163.com (Q.Z.); \\ r790507807@gmail.com (Q.-R.Z.); trustlou@163.com (J.-W.L.); chenpeidong1970@163.com (P.-D.C.); \\ yaowf@njucm.edu.cn (W.-F.Y.); tw845@163.com (W.-W.T.); 18260028211@163.com (G.-C.D.); \\ 18260028237@163.com (K.W.) \\ 2 College of Pharmacy and Shaanxi Collaborative Innovation Center of Chinese Medicinal Resources \\ Industrialization, Shaanxi University of Chinese Medicine, Xi'an 712046, China; 2051001@sntcm.edu.cn \\ * Correspondence: zhangli@njucm.edu.cn; Tel.: +86-138-5147-2740; Fax: +86-025-8581-1524
}

Received: 30 October 2017; Accepted: 4 December 2017; Published: 8 December 2017

\begin{abstract}
In this research, a new triterpenoid, tirucalla-8,24-diene-3 $\beta, 11 \beta$-diol-7-one (1), and eupha-8,24-diene-3 $\beta, 11 \beta$-diol-7-one (2), which was isolated from Euphorbia kansui for the first time, together with twelve other known compounds (3-14), were isolated from the ethyl acetate extract of Euphorbia kansui. Their structures were elucidated based on High resolution electrospray ionization mass spectrometry (HR-ESI-MS), Infrared Spectroscopy (IR), 1D and 2D Nuclear Magnetic Resonance (NMR) data. Both constituents $\mathbf{1}$ and $\mathbf{2}$ exhibited moderate cytotoxicity against colon cancer HCT-116, gastric cancer MKN-45 and breast cancer MCF-7.
\end{abstract}

Keywords: Euphane and Tirucallane; triterpenes; cytotoxicity; Euphorbia kansui

\section{Introduction}

The plants of Euphorbia contain more than 2000 species spread all over the world, and about 80 species distribute in China [1,2]. The dried root of Euphorbia kansui has long been used for the treatment of asthma, edema and ascites in traditional Chinese medicine. The structure type of the compounds in Euphorbia kansui are diterpenes, triterpenes, flavonoids, phenolic and acids [3-5]. Among them, diterpenes and triterpenoids are the main compounds in Euphorbia kansui, which show a wide range of pharmacological activities, such as antiviral, skin irritating and modulation of multidrug resistance effects [6-9]. A new tirucallane-type triterpene named tirucalla-8,24-diene-3 $\beta, 11 \beta$-diol-7-one (1) was first isolated from natural plants, and an euphane-type triterpene named eupha-8,24-diene-3 $\beta, 11 \beta$-diol-7-one (2) (Figure 1) was isolated from Euphorbia kansui for the first time in our present study. The two compounds were identified by $1 \mathrm{D}$ and $2 \mathrm{D}$ NMR including Heteronuclear Single Quantum Coherence (HSQC), Heteronuclear Multiple-Bond Correlation (HMBC), COrrelation SpectroscopY (COSY), Nuclear Overhauser Effect Spectroscopy (NOESY) and HR-ESI-MS data. 

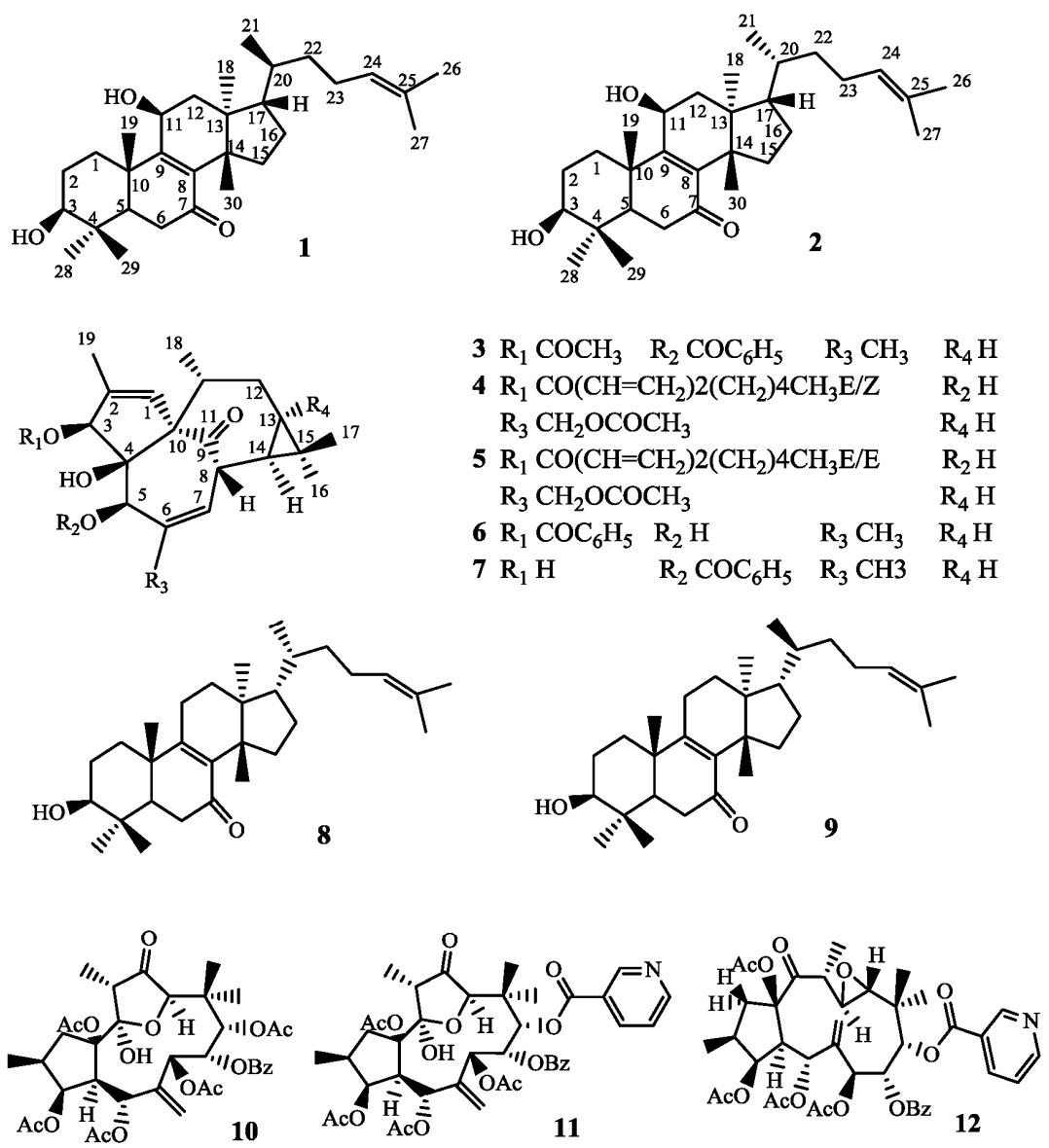<smiles>CC(=O)C=C=C=C=C(C(=O)O)c1ccccc1</smiles>
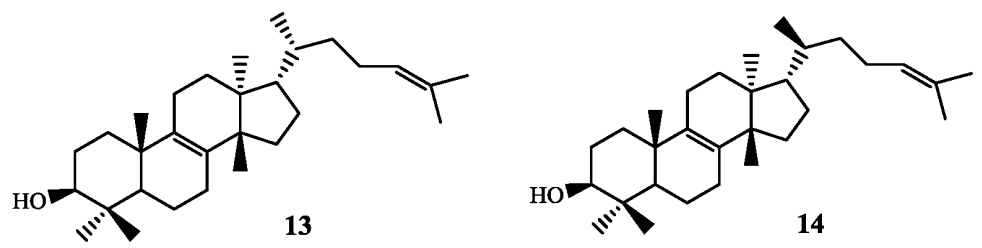

Figure 1. Chemical structures of Compounds 1-14.

\section{Results and Discussion}

Compound 1 was obtained as a white powder. The molecular formula $\mathrm{C}_{30} \mathrm{H}_{48} \mathrm{O}_{3}$ was established by HR-ESI-MS ( $m / z 457.3770[\mathrm{M}+\mathrm{H}]^{+}$, calcd. 457.3682) (Figure 1-1), IR (KBr) $v_{\max } 3371,2977,2861$, 1635, 1456, 1376, 1036, $622 \mathrm{~cm}^{-1}$ (Figure 1-2), UV (MeOH) $\lambda_{\max } 253 \mathrm{~nm}$ (Figure 1-3) (Figures 1-1, 1-2, 1-3, see the Supplementary Materials); The comparison of ${ }^{1} \mathrm{H}-\mathrm{NMR},{ }^{13} \mathrm{C}-\mathrm{NMR}$ (Tables 1 and 2, Figures 1-4 and 1-5, see the Supplementary Materials) and NOESY data (Figure 2) showed that compound 1 and the known compound 2 [10] were semblable in structure, except that a Hydrogen at C-11 of compound 2 was superseded by a hydroxyl group in compound 1, which was verified by correlations of H-11 $\left(\delta_{\mathrm{H}} 4.70, \mathrm{t}, J=8.2 \mathrm{~Hz}\right)$ with C-8 $\left(\delta_{\mathrm{C}} 140.46\right), \mathrm{C}-9\left(\delta_{\mathrm{C}} 161.25\right)$ and $\mathrm{C}-12\left(\delta_{\mathrm{C}} 42.79\right)$ in HMBC spectrum (Figure 3). Compared with ${ }^{1} \mathrm{H}-\mathrm{NMR}$ and ${ }^{13} \mathrm{C}-\mathrm{NMR}$ of $\mathbf{1}$ and 2 , we can clearly see the differences between compound 2: $\mathrm{H}-\mathrm{C}(21) \delta_{\mathrm{H}} 0.88, \mathrm{H}-\mathrm{C}(22) \delta_{\mathrm{H}} 1.08-1.13(\mathrm{~m}), 1.56-1.62(\mathrm{~m}), \mathrm{C}-20 \delta_{\mathrm{C}}$ 35.61, C-22 $\left.\delta_{\mathrm{C}} 35.51\right)$ and compound 1 : H-C $(21) \delta_{\mathrm{H}} 0.94, \mathrm{H}-\mathrm{C}(22) \delta_{\mathrm{H}} 1.03-1.12(\mathrm{~m}), \mathrm{C}-20 \delta_{\mathrm{C}} 36.03, \mathrm{C}-22$ $\delta_{\mathrm{C}}$ 36.24. In the HSQC plot (Figure 1-6, see the Supplementary Materials), $\delta_{\mathrm{H}} 1.03-1.12$ and 1.40-1.47 
showed correlations with $\mathrm{C}(22), \mathrm{C}(20)$ at $\delta_{\mathrm{C}} 36.24,36.03$ respectively, which indicated compound $\mathbf{1}$, $\mathrm{H}-\mathrm{C}(22) \delta_{\mathrm{H}} 1.03-1.12(\mathrm{~m})$. The relative configuration of 1 was determined by the ${ }^{1} \mathrm{H}-\mathrm{NMR}$ (Table 1 ) and NOESY data. ${ }^{1} \mathrm{H}-\mathrm{NMR}$ chemical shift of $\mathrm{CH}_{3}-21\left(\delta_{\mathrm{H}} 0.94, \mathrm{~d}, J=6.6 \mathrm{~Hz}\right)$ confirmed that compound 1 was classified as the tirucallane series [11-13]. The large coupling constants $\mathrm{H}-\mathrm{C}(3)$ $\left(\delta_{\mathrm{H}} 3.31, J=9.5,6.4 \mathrm{~Hz}\right)$ obviously indicated that the $3-\mathrm{OH}$ group was in equatorial $\beta$-position $[10,14]$. The NOESY correlations (Figure 2$) \mathrm{H}-\mathrm{C}(3)\left(\delta_{\mathrm{H}} 3.31\right) / \mathrm{H}-\mathrm{C}(5)\left(\delta_{\mathrm{H}} 1.65-1.68\right), \mathrm{H}-\mathrm{C}(3)\left(\delta_{\mathrm{H}} 3.31\right) / \mathrm{CH}_{3}-28$ $\left(\delta_{\mathrm{H}} 1.00\right), \mathrm{H}-\mathrm{C}(11)\left(\delta_{\mathrm{H}} 4.70\right) / \mathrm{CH}_{3}-18\left(\delta_{\mathrm{H}} 0.71\right), \mathrm{CH}_{3}-30\left(\delta_{\mathrm{H}} 1.15\right) / \mathrm{H}-\mathrm{C}(17)\left(\delta_{\mathrm{H}} 1.54-1.61\right), \mathrm{CH}_{3}-29$ $\left(\delta_{\mathrm{H}} 0.92\right) / \mathrm{CH}_{3}-19\left(\delta_{\mathrm{H}} 1.28\right), \mathrm{CH}_{3}-18\left(\delta_{\mathrm{H}} 0.71\right) / \mathrm{CH}_{3}-19\left(\delta_{\mathrm{H}} 1.28\right)$, showed that $\mathrm{H}-\mathrm{C}(3), \mathrm{H}-\mathrm{C}(5), \mathrm{H}-\mathrm{C}(17)$, $\mathrm{CH}_{3}-28$, were all in $\alpha$-orientation, whereas 11-OH, $\mathrm{CH}_{3}-19, \mathrm{CH}_{3}-30$ and $\mathrm{CH}_{3}-29$ were all in $\beta$-orientation. Furthermore, compound 1 showed NOESY correlations between $\mathrm{CH}_{3}-18$ and $\mathrm{H}-\mathrm{C}(20)\left(\delta_{\mathrm{H}} 1.40-1.47\right)$ and $\mathrm{CH}_{3}-21$, between $\mathrm{CH}_{3}-21$ and $\mathrm{H}-12 \beta\left(\delta_{\mathrm{H}}\right.$ 2.38-2.46). These correlations were consistent with those of tirucallane-type triterpenes [14]. As a result, the structure of compound $\mathbf{1}$ was identified as tirucalla-8,24-diene-3 $\beta, 11 \beta$-diol-7-one.

Table 1. ${ }^{1} \mathrm{H}-\mathrm{NMR}$ data for compounds $\mathbf{1}$ and 2.

\begin{tabular}{|c|c|c|}
\hline Position & Compound 1 & Compound 2 \\
\hline $1 \alpha$ & $1.56-1.62(\mathrm{~m})$ & $1.52-1.60(\mathrm{~m})$ \\
\hline $1 \beta$ & $2.41-2.47(\mathrm{~m})$ & $2.40-2.46(\mathrm{~m})$ \\
\hline 2 & $1.70-1.79(\mathrm{~m})$ & $1.70-1.79(\mathrm{~m})$ \\
\hline $3 \alpha$ & $3.31(\mathrm{dd}, J=6.4,9.6)$ & $3.31(\mathrm{dd}, J=6.4,9.6)$ \\
\hline 5 & $1.65-1.68(\mathrm{~m})$ & $1.62-1.68(\mathrm{~m})$ \\
\hline 6 & $2.40-2.47(\mathrm{~m})$ & $2.40-2.48(\mathrm{~m})$ \\
\hline 11 & $4.70(\mathrm{t}, J=8.2)$ & $4.69(\mathrm{t}, J=8.2)$ \\
\hline $12 \alpha$ & $1.76-1.81(\mathrm{~m})$ & $1.74-1.81(\mathrm{~m})$ \\
\hline $12 \beta$ & $2.38-2.46(\mathrm{~m})$ & $2.35-2.43(\mathrm{~m})$ \\
\hline $15 \alpha$ & $2.10-2.12(\mathrm{~m})$ & $2.12-2.19(\mathrm{~m})$ \\
\hline $15 \beta$ & $1.42-1.46(\mathrm{~m})$ & $1.40-1.46(\mathrm{~m})$ \\
\hline $16 \alpha$ & $1.93-1.99(\mathrm{~m})$ & $1.90-1.94(\mathrm{~m})$ \\
\hline $16 \beta$ & $1.28-1.33(\mathrm{~m})$ & $1.28-1.32(\mathrm{~m})$ \\
\hline 17 & $1.54-1.61(\mathrm{~m})$ & $1.55-1.60(\mathrm{~m})$ \\
\hline 18 & $0.71(\mathrm{~s})$ & $0.73(\mathrm{~s})$ \\
\hline 19 & $1.28(\mathrm{~s})$ & $1.27(\mathrm{~s})$ \\
\hline 20 & $1.40-1.47(\mathrm{~m})$ & $1.40-1.46(\mathrm{~m})$ \\
\hline 21 & $0.94(\mathrm{~d}, J=6.6)$ & $0.88(\mathrm{~d}, J=6.4)$ \\
\hline 22 & $1.03-1.12(\mathrm{~m})$ & $1.08-1.13(\mathrm{~m}) 1.56-1.62(\mathrm{~m})$ \\
\hline 23 & $1.83-1.91(\mathrm{~m}) 2.01-2.08(\mathrm{~m})$ & $1.84-1.90(\mathrm{~m}) 1.98-2.02(\mathrm{~m})$ \\
\hline 24 & $5.09(\mathrm{t}, J=7.2)$ & $5.09(\mathrm{t}, J=7.2)$ \\
\hline 26 & $1.70(\mathrm{~s})$ & $1.70(\mathrm{~s})$ \\
\hline 27 & $1.62(\mathrm{~s})$ & $1.63(\mathrm{~s})$ \\
\hline 28 & $1.00(\mathrm{~s})$ & $1.01(\mathrm{~s})$ \\
\hline 29 & $0.92(\mathrm{~s})$ & $0.93(\mathrm{~s})$ \\
\hline 30 & $1.15(\mathrm{~s})$ & $1.16(\mathrm{~s})$ \\
\hline
\end{tabular}

Record in $\mathrm{CDCl}_{3}, 400 \mathrm{MHz}$ for ${ }^{1} \mathrm{H}, \delta$ in $\mathrm{ppm}, J=\mathrm{Hz}$.

Table 2. ${ }^{13} \mathrm{C}-\mathrm{NMR}$ data of compounds $\mathbf{1}$ and $\mathbf{2}$.

\begin{tabular}{ccc}
\hline Position & Compound 1 & Compound 2 \\
\hline 1 & 33.68 & 33.67 \\
2 & 27.37 & 27.36 \\
3 & 78.27 & 78.26 \\
4 & 39.07 & 39.06 \\
5 & 49.25 & 49.25 \\
6 & 35.84 & 35.84 \\
7 & 200.10 & 200.16 \\
8 & 140.46 & 140.44 \\
9 & 161.25 & 161.30 \\
10 & 39.58 & 39.58 \\
\hline
\end{tabular}


Table 2. Cont

\begin{tabular}{ccc}
\hline Position & Compound $\mathbf{1}$ & Compound 2 \\
\hline 11 & 68.11 & 68.11 \\
12 & 42.79 & 42.83 \\
13 & 46.19 & 46.19 \\
14 & 47.95 & 48.02 \\
15 & 31.88 & 31.81 \\
16 & 27.77 & 27.80 \\
17 & 49.13 & 48.69 \\
18 & 16.06 & 16.24 \\
19 & 19.70 & 19.67 \\
20 & 36.03 & 35.61 \\
21 & 18.68 & 18.76 \\
22 & 36.24 & 35.51 \\
23 & 24.86 & 24.82 \\
24 & 124.98 & 124.90 \\
25 & 131.09 & 131.14 \\
26 & 25.68 & 25.73 \\
27 & 17.62 & 17.70 \\
28 & 27.59 & 27.59 \\
29 & 15.18 & 15.19 \\
30 & 25.62 & 25.70 \\
\hline
\end{tabular}

Record in $\mathrm{CDCl}_{3}, 100 \mathrm{MHz}$ for ${ }^{13} \mathrm{C}, \delta$ in ppm, $J=\mathrm{Hz}$.

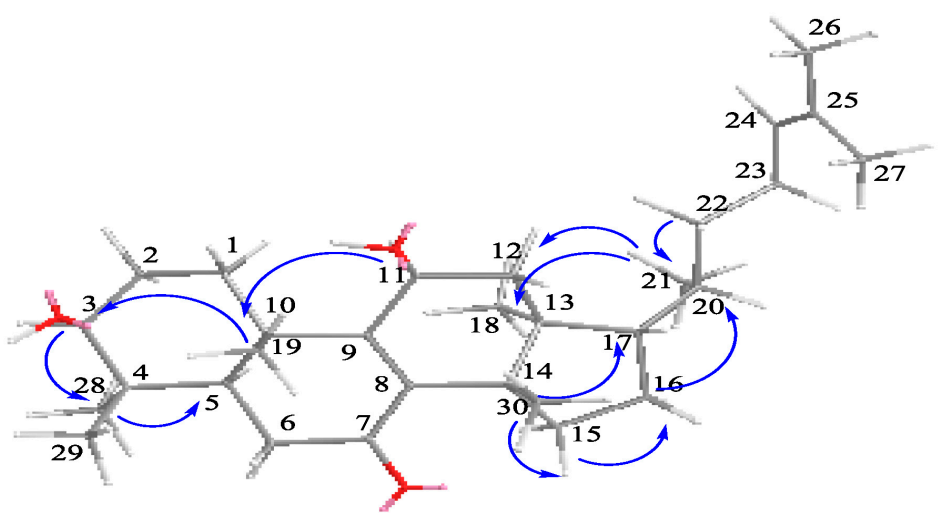

Compound 1

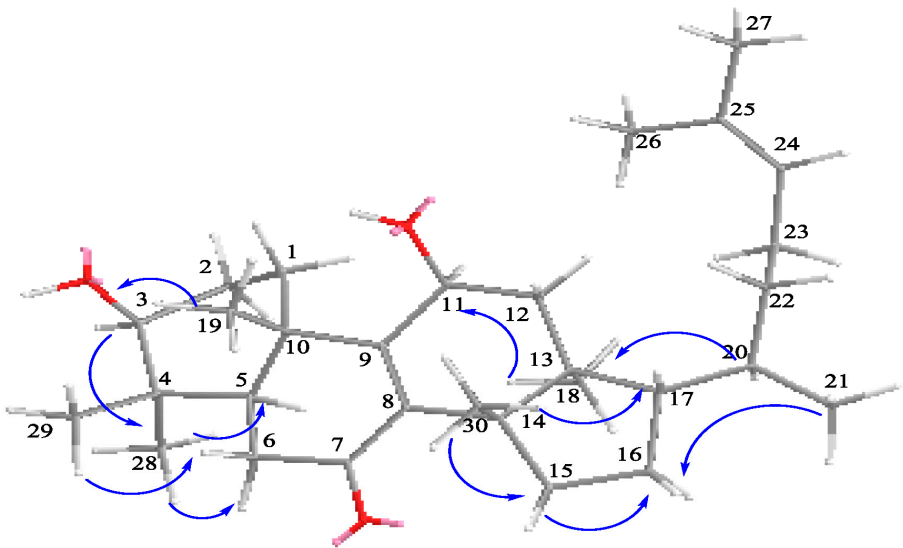

Compound 2

Figure 2. Key NOESY correlations for $\mathbf{1}$ and 2. 

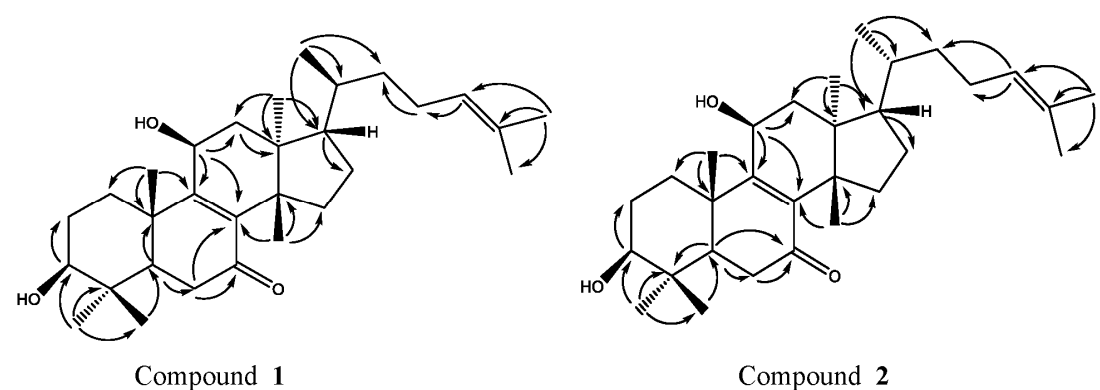

Figure 3. Key HMBC correlations for $\mathbf{1}$ and 2.

The comparison of ${ }^{1} \mathrm{H}-\mathrm{NMR},{ }^{13} \mathrm{C}-\mathrm{NMR}$ (Tables 1 and 2) and NOESY data (Figure 2) showed that compound 2 and the known Compound $\mathbf{1}$ [10] were semblable in structure, except that a Hydrogen at C-11 of Compound $\mathbf{1}$ was superseded by a hydroxyl group in compound $\mathbf{2}$, which was proven by correlations of $\mathrm{H}-11\left(\delta_{\mathrm{H}} 4.69, \mathrm{t}, J=8.2 \mathrm{~Hz}\right)$ with $\mathrm{C}-8\left(\delta_{\mathrm{C}} 140.44\right), \mathrm{C}-9\left(\delta_{\mathrm{C}} 161.30\right)$ and $\mathrm{C}-12\left(\delta_{\mathrm{C}} 42.83\right)$ in HMBC spectrum (Figure 3$)$. The large coupling constants $\mathrm{H}-\mathrm{C}(3)\left(\delta_{\mathrm{H}} 3.31, J=9.5,6.4 \mathrm{~Hz}\right)$ obviously indicated that the 3-OH group was in equatorial $\beta$-position [11,12]. The NOESY correlations (Figure 2) $\mathrm{H}-\mathrm{C}(3)\left(\delta_{\mathrm{H}} 3.31\right) / \mathrm{H}-\mathrm{C}(5)\left(\delta_{\mathrm{H}} 1.62-1.68\right), \mathrm{H}-\mathrm{C}(3)\left(\delta_{\mathrm{H}} 3.31\right) / \mathrm{CH}_{3}-28\left(\delta_{\mathrm{H}} 1.01\right), \mathrm{H}-\mathrm{C}(11)\left(\delta_{\mathrm{H}} 4.69\right) / \mathrm{CH}_{3}-18$ $\left(\delta_{\mathrm{H}} 0.73\right), \mathrm{CH}_{3}-30\left(\delta_{\mathrm{H}} 1.16\right) / \mathrm{H}-\mathrm{C}(17)\left(\delta_{\mathrm{H}} 1.55-1.60\right), \mathrm{CH}_{3}-29\left(\delta_{\mathrm{H}} 0.93\right) / \mathrm{CH}_{3}-19\left(\delta_{\mathrm{H}} 1.27\right), \mathrm{CH}_{3}-18$ $\left(\delta_{\mathrm{H}} 0.73\right) / \mathrm{CH}_{3}-19\left(\delta_{\mathrm{H}} 1.27\right)$, showed that $\mathrm{H}-\mathrm{C}(3), \mathrm{H}-\mathrm{C}(5), \mathrm{H}-\mathrm{C}(17)$, and $\mathrm{CH}_{3}-28$ were all in $\alpha$-orientation, whereas $11-\mathrm{OH}, \mathrm{CH}_{3}-19, \mathrm{CH}_{3}-30$ and $\mathrm{CH}_{3}-29$ were in $\beta$-orientation, and no correlations between $\mathrm{CH}_{3}-21 / \mathrm{CH}_{3}-18[10,15]$ indicated that it belonged to the euphane-type triterpenes. The ${ }^{1} \mathrm{H}-\mathrm{NMR}$ chemical shift of $\mathrm{CH}_{3}-21\left(\delta_{\mathrm{H}} 0.88, \mathrm{~d}, J=6.4 \mathrm{~Hz}\right)$ further confirmed that compound 2 pertained to the euphane rather than the tirucallane series [12,13]. As a result, compound 2 was elucidated to be eupha-8,24-diene-3 $\beta, 11 \beta$-diol-7-one.

All 12 of the known compounds (3-14) were identified according to the spectroscopic data $\left({ }^{1} \mathrm{H}-\mathrm{NMR},{ }^{13} \mathrm{C}-\mathrm{NMR}\right.$, see the Supplementary Materials) together with the comparsion of those reported, kansuiphorin C (3) [16], 3-O-(2'E,4'Z-decadienoyl)-20-O-acetylingenol (4) [4], 3-O-(2'E,4'E-decadienoyl)-20-O-acetylingenol (5) [4], 3-O-benzoyl-20-deoxyingenol (6) [4], 5-O-benzoyl-20-deoxyingenol (7) [4], kansenone (8) [10], epi-kansenone (9) [10], kansuinin A (10) $[4,17]$, kansuinin D (11) [4], kansuinin E (12) [4], euphol (13) [4,18], and tirucallol (14) [4,19].

Compounds 1 and 2 were assessed for their inhibitory effects on HCT-116, MKN-45 and MCF-7 cell lines (Table 3), as well as L-O2 and GES-1 cell lines (Table 4). The results show that compounds 1 and 2 inhibit normal cells (L-O2 and GES-1) less than cancer cells (HCT-116, MKN-45 and MCF-7), and compounds 1 and 2 presented definite anticancer activities with $\mathrm{IC}_{50}$ values of $20.84 \pm 1.28$ and $33.97 \pm 2.15 \mu \mathrm{M}$ against HCT-116 cells, $10.18 \pm 1.36$ and $14.95 \pm 1.82 \mu \mathrm{M}$ against MKN-45 cells, and $10.82 \pm 1.18$ and $20.11 \pm 2.16 \mu \mathrm{M}$ against MCF-7 cells, respectively. kansenone induces apoptosis through both the death receptor and mitochondrial pathways [5], and compounds $\mathbf{1}$ and $\mathbf{2}$ were similar with kansenone in structure, excluding that a Hydrogen at C-11 of kansenone was superseded by a hydroxyl group in compounds $\mathbf{1}$ and $\mathbf{2}$, thus compounds $\mathbf{1}$ and $\mathbf{2}$ may induce apoptosis in the same way as kansenone. Further research will be conducted on the anticancer mechanism of compounds 1 and 2.

Table 3. Cytotoxicity of compounds 1 and 2 against three human cancer cell lines.

\begin{tabular}{cccc}
\hline \multirow{2}{*}{ Compound } & \multicolumn{3}{c}{ IC $_{\mathbf{5 0}}(\boldsymbol{\mu M})$} \\
\cline { 2 - 4 } & HCT-116 & MKN-45 & MCF-7 \\
\hline $\mathbf{1}$ & $20.84 \pm 1.28$ & $10.18 \pm 1.36$ & $10.82 \pm 1.18$ \\
$\mathbf{2}$ & $33.97 \pm 2.15$ & $14.95 \pm 1.82$ & $20.11 \pm 2.16$ \\
Cisplatin & $8.465 \pm 0.84$ & $6.142 \pm 1.12$ & $9.035 \pm 0.92$ \\
\cline { 2 - 4 } 5-Fu & $6.172 \pm 2.03$ & $2.624 \pm 2.06$ & $1.629 \pm 1.42$ \\
\hline
\end{tabular}


Table 4. Cytotoxicity of compounds $\mathbf{1}$ and $\mathbf{2}$ against two human normal cell lines.

\begin{tabular}{ccc}
\hline \multirow{2}{*}{ Compound } & \multicolumn{2}{c}{ IC $_{\mathbf{5 0}}(\boldsymbol{\mu M})$} \\
\cline { 2 - 3 } & L-O2 & GES-1 \\
\hline $\mathbf{1}$ & $56.98 \pm 1.74$ & $40.99 \pm 0.85$ \\
$\mathbf{2}$ & $49.89 \pm 2.12$ & $40.27 \pm 1.28$ \\
\hline
\end{tabular}

\section{Materials and Methods}

\subsection{General Experimental Procedures}

HPLC: Hanbon NP 7000 (Jiangsu Hanbang Technology Companies, Huaian, China) Serials pump with an NU 3000 Serials UV-Vis detector (Jiangsu Hanbang Technology Companies, Huaian, China), Phecda Si $(20 \times 250 \mathrm{~mm}, 5 \mu \mathrm{m})$; Waters 1525 with a 2996 Diode Array Detector (DAD) (Waters, Milford, CT, USA), XBrige-Prep $C_{18}(150 \times 19 \mathrm{~mm}, 5 \mu \mathrm{m})$, (Ultimate XB-C8, $\left.30 \times 150 \mathrm{~mm}, 5 \mu \mathrm{m}\right)$. IR spectra were gained on a Nicole Is5 of Thermo Fisher spectrophotometer (Nicolet Instrument Corporation, Madison, WI, USA). The NMR spectra were measured on Avance 400 spectrometers (Bruker, Karlsruhe, Germany), with TMS as an internal standard. The UV spectra were measured on a Shimadzu UV-2401 UV-Vis spectrophotometer (Shimadzu, Kyoto, Japan). The HR-ESI-MS data were obtained by using a LTQ Orbitrap MS (Thermo Fisher Scientific, San Jose, CA, USA). Column chromatography (CC): silica gel (200-300 mesh, Qingdao Marine Chemical Industry, Qingdao, China).

\subsection{Plant Materials}

The dried root of Euphorbia kansui was collected from Red River valley of Baoji, Shaanxi Province of China, in October 2015 and was identified by Prof. Yu Ping Tang (college of pharmacy, Nanjing University of Chinese Medicine, Nanjing, China). The voucher specimen (20151020) has been deposited in the Herbarium of college of pharmacy, Nanjing University of Chinese Medicine (Nanjing, China).

\subsection{Extraction and Isolation}

The dried roots of Euphorbia kansui (12.2 kg) were extracted twice (each time for $2 \mathrm{~h}$ ) with $95 \%$ $\mathrm{EtOH}$ under reflux to give the $95 \% \mathrm{EtOH}$ extract $(871.9 \mathrm{~g})$ by evaporation of the solvent under reduced pressure, and then the $95 \% \mathrm{EtOH}$ extract was extracted with ethyl acetate (EtOAc) to obtain ethyl acetate extract $(530.8 \mathrm{~g})$. Finally, the fraction of EtOAc was subjected to silica gel column chromatography $(14 \times 59 \mathrm{~cm})$ with a gradient elution (Pet and ethyl acetate, 100:1-1:1) to get fractions A-T. Fr. G (2 g) was eluted with Pet:EtOAc (100:20). Compound 1 (40.8 mg) was isolated by HPLC (Pet:EtOAc, 100:38), and further purified by reversed-phase HPLC $\left(\mathrm{MeCN}: \mathrm{H}_{2} \mathrm{O}, 70: 30\right)$ flow rate $16 \mathrm{~mL} / \mathrm{min}$ $\left(t_{R} 15.342 \mathrm{~min}\right.$ ). Compound 2 (70.3 mg) was isolated by HPLC (Pet:EtOAc, 100:30), and further purified by reversed-phase HPLC (MeCN: $\left.\mathrm{H}_{2} \mathrm{O}, 70: 30\right)$ flow rate $16 \mathrm{~mL} / \mathrm{min}\left(\mathrm{t}_{\mathrm{R}} 16.060 \mathrm{~min}\right)$. Fr. A (18 g) was eluted with Pet:EtOAc (100:3). Compound 13 (6.082 g) was isolated by HPLC (MeCN: $\left.\mathrm{H}_{2} \mathrm{O}, 95: 5\right)$ with (Ultimate $\mathrm{XB}-\mathrm{C} 8,30 \times 150 \mathrm{~mm}, 5 \mu \mathrm{m}$ ) flow rate $16 \mathrm{~mL} / \mathrm{min}\left(\mathrm{t}_{\mathrm{R}} 35.452 \mathrm{~min}\right.$ ). Compound 14 (782.5 mg) was isolated by HPLC (MeCN: $\left.\mathrm{H}_{2} \mathrm{O}, 95: 5\right)$ with (Ultimate XB-C8, $30 \times 150 \mathrm{~mm}, 5 \mu \mathrm{m}$ ) flow rate $16 \mathrm{~mL} / \mathrm{min}\left(\mathrm{t}_{\mathrm{R}} 33.645 \mathrm{~min}\right)$. Fr. B (3 g) was eluted with Pet:EtOAc (100:5). Compound 6 (320 mg) was isolated by HPLC (Pet:EtOAc, 100:10) flow rate $16 \mathrm{~mL} / \mathrm{min}\left(\mathrm{t}_{\mathrm{R}} 24.003 \mathrm{~min}\right)$. Compound 7 (46 mg) was isolated by HPLC (Pet:EtOAc, 100:10) flow rate $16 \mathrm{~mL} / \mathrm{min}\left(t_{\mathrm{R}} 22.209 \mathrm{~min}\right)$. Fr. C (5 g) was eluted with Pet:EtOAc (100:6). Compound 3 (920 mg) was isolated by HPLC (Pet:EtOAc, 100:11) flow rate $16 \mathrm{~mL} / \mathrm{min}\left(t_{\mathrm{R}} 24.128 \mathrm{~min}\right)$. Fr. D (2 g) was eluted with Pet:EtOAc (100:8). Compound 8 (161 mg) was isolated by HPLC (Pet:EtOAc, 100:15) flow rate $16 \mathrm{~mL} / \mathrm{min}\left(\mathrm{t}_{\mathrm{R}} 23.218 \mathrm{~min}\right)$. Compound $9(28 \mathrm{mg}$ ) was isolated by HPLC (Pet:EtOAc, 100:15) flow rate $16 \mathrm{~mL} / \mathrm{min}\left(\mathrm{t}_{\mathrm{R}} 20.674 \mathrm{~min}\right)$. Fr. E ( $\left.2 \mathrm{~g}\right)$ was eluted with Pet:EtOAc (100:13). Compound $4(80 \mathrm{mg})$ was isolated by HPLC (Pet:EtOAc, 100:20) flow rate $16 \mathrm{~mL} / \mathrm{min}\left(\mathrm{t}_{\mathrm{R}} 21.097 \mathrm{~min}\right)$. Compound 5 (40 mg) was isolated by HPLC (Pet:EtOAc, 100:20) flow 
rate $16 \mathrm{~mL} / \mathrm{min}\left(\mathrm{t}_{\mathrm{R}} 24.298 \mathrm{~min}\right)$. Fr. H (10 g) was eluted with Pet:EtOAc (100:55). Compound 10 (186 mg) was isolated by HPLC (Pet:EtOAc, 100:40), and further purified by reversed-phase HPLC ( $\left.\mathrm{MeCN}: \mathrm{H}_{2} \mathrm{O}, 70: 30\right)$ flow rate $16 \mathrm{~mL} / \mathrm{min}\left(\mathrm{t}_{\mathrm{R}} 10.502 \mathrm{~min}\right)$. Compound $11(60 \mathrm{mg})$ was isolated by HPLC (Pet:EtOAc, 100:40), and further purified by reversed-phase HPLC (MeCN: $\left.\mathrm{H}_{2} \mathrm{O}, 70: 30\right)$ flow rate $16 \mathrm{~mL} / \mathrm{min}$ ( $t_{\mathrm{R}} 9.702 \mathrm{~min}$ ). Compound $12(80 \mathrm{mg}$ ) was isolated by HPLC (Pet:EtOAc, 100:40), and further purified by reversed-phase HPLC ( $\left.\mathrm{MeCN}: \mathrm{H}_{2} \mathrm{O}, 70: 30\right)$ flow rate $16 \mathrm{~mL} / \mathrm{min}\left(\mathrm{t}_{\mathrm{R}} 11.302 \mathrm{~min}\right)$.

\subsection{Cytotoxicity Test}

Cytotoxicity of two compounds against HCT-116, MKN-45 and MCF-7 cancer cell lines (American Type Culture Collection, ATCC, Manassas, VA, USA), normal liver cell L-O2 (Zhongqiaoxinzhou Biotech, Shanghai, China) and gastric epithelial cell GES-1 (Nanjingkebai Biotech, Nanjing, China) were evaluated with the MTT (3-(4,5-dimethylthiazol-2-yl)-2,5-diphenylt-etrazolium bromide) method as described in the literature [20,21]. All cells were cultured in Dulbecco's modified Eagle's medium (DMEM) supplemented with 10\% fetal bovine serum, three cancer cells were seeded in 96-well plate at a concentration of $8 \times 10^{4}$ cells $/ \mathrm{mL}$, two normal cells L-O2 and GES- 1 were seeded in 96-well plate at a concentration of $1 \times 10^{4}$ cells $/ \mathrm{mL}$ and $1 \times 10^{5}$ cells $/ \mathrm{mL}$ respectively [21], and incubated for $24 \mathrm{~h}$ in humidifyed atmosphere with $5 \% \mathrm{CO}_{2}$ at $37^{\circ} \mathrm{C}$. One hundred microliters of cells were treated with compound 1 and 2 at different doses of $1.25,2.5,5,10,20$ and $40 \mu \mathrm{g} / \mathrm{mL}$ in dimethyl sulfoxide (DMSO) in triplicate for $48 \mathrm{~h}$ at $37{ }^{\circ} \mathrm{C}$ with $5 \% \mathrm{CO}_{2}$. Then, each of them were added with $20 \mu \mathrm{L}$ of MTT $(5.0 \mathrm{mg} / \mathrm{mL})$ and incubated for further $4 \mathrm{~h}$, the growth medium was removed from all the wells. Finally, $150 \mu \mathrm{L}$ DMSO were added to every sample. Cisplatin (Qilu pharmaceutical, Jinan, China) and 5-fluorouracil (5-Fu) (Sichuan Kangyi, pharmaceutical, Chengdu, China) served as positive control. Absorbance was determined by a microplate spectrophotometer at $490 \mathrm{~nm}$.

\section{Conclusions}

The article reported two compounds, $\mathbf{1}$ and 2, which are triterpenes, as well as twelve other known compounds (3-14). Compound 1 is a new tirucallane-type triterpene named tirucalla-8,24-diene-3 $\beta, 11 \beta$-diol-7-one. Compound 2 was isolated from Euphorbia kansui for the first timeand named eupha-8,24-diene-3 $\beta, 11 \beta$-diol-7-one. They also display effective anticancer activities against HCT-116, MKN-45 and MCF-7 cells. As we all know, Euphorbia kansui has pharmacological activities including tumor inhibition and antiviral effects [22,23]; this study further confirmed kansui may be a potential candidate for anticancer including colon cancer, gastric cancer and breast cancer and inferred that compounds $\mathbf{1}$ and $\mathbf{2}$ may be the main material basis of anticancer for Euphorbia kansui.

Some features about compounds 1, 2, 8, 9, 13 and 14 may be drawn based on their chemical structures. Above all, the $\mathrm{CH}_{3}-21$ of compounds 9 and 14 were all in $\beta$-orientation and their ${ }^{1} \mathrm{H}-\mathrm{NMR}$ chemical shift of $\mathrm{CH}_{3}-21$ at $\left(\delta_{\mathrm{H}} 0.94, \mathrm{~d}, J=6.6 \mathrm{~Hz}\right)$, whereas the $\mathrm{CH}_{3}-21$ of compounds 8 and 13 were all in $\alpha$-orientation and their ${ }^{1} \mathrm{H}-\mathrm{NMR}$ chemical shift of $\mathrm{CH}_{3}-21$ at $\left(\delta_{\mathrm{H}} 0.88, \mathrm{~d}, J=6.4 \mathrm{~Hz}\right)[4,18,19]$. The C-20 and C-22 of compound 9 had a chemical shift greater than compound 8 . The C-20 and C-22 of compound 14 was larger than compound $\mathbf{1 3}$ (Table 5), which were identical with the ${ }^{1} \mathrm{H}-\mathrm{NMR}$ and ${ }^{13} \mathrm{C}-\mathrm{NMR}$ of compounds $\mathbf{1}$ and $\mathbf{2}$, respectively. Then, the polarity order of compound $\mathbf{9}$ was larger than compound 8. Compound $\mathbf{1 4}$ is also greater than $\mathbf{1 3}$ in the same way, which were also the same as the polarity order of compounds $\mathbf{1}$ and $\mathbf{2}$. Thus, the different positions of $\mathrm{CH}_{3}-21$ of compounds $\mathbf{1}$ and $\mathbf{2 , 8}$ and $\mathbf{9}$, and $\mathbf{1 3}$ and $\mathbf{1 4}$ may have a good correlation with their polarity order. 
Table 5. ${ }^{13} \mathrm{C}-\mathrm{NMR}$ data of compounds $8,9,13$ and 14 .

\begin{tabular}{|c|c|c|c|c|}
\hline Position & Compound 8 & Compound 9 & Compound 13 & Compound 14 \\
\hline 1 & 34.61 & 34.61 & 35.26 & 35.26 \\
\hline 2 & 27.40 & 27.41 & 27.95 & 27.92 \\
\hline 3 & 78.07 & 78.06 & 79.00 & 79.03 \\
\hline 4 & 38.82 & 38.83 & 38.94 & 38.94 \\
\hline 5 & 48.19 & 48.24 & 50.97 & 50.97 \\
\hline 6 & 35.77 & 35.78 & 18.95 & 18.95 \\
\hline 7 & 198.37 & 198.35 & 27.68 & 27.67 \\
\hline 8 & 138.94 & 138.93 & 134.03 & 134.08 \\
\hline 9 & 165.46 & 165.48 & 133.55 & 133.51 \\
\hline 10 & 39.27 & 39.27 & 37.24 & 37.27 \\
\hline 11 & 23.73 & 23.67 & 21.53 & 21.45 \\
\hline 12 & 29.95 & 29.87 & 30.90 & 30.80 \\
\hline 13 & 44.62 & 44.61 & 44.12 & 44.11 \\
\hline 14 & 47.68 & 47.61 & 50.03 & 50.12 \\
\hline 15 & 31.39 & 31.45 & 29.77 & 28.83 \\
\hline 16 & 28.67 & 28.65 & 28.14 & 28.05 \\
\hline 17 & 48.24 & 48.76 & 49.64 & 49.96 \\
\hline 18 & 15.73 & 15.54 & 15.63 & 15.52 \\
\hline 19 & 18.60 & 18.61 & 20.15 & 20.14 \\
\hline 20 & 35.65 & 36.16 & 35.88 & 36.33 \\
\hline 21 & 18.90 & 18.75 & 18.92 & 18.69 \\
\hline 22 & 35.52 & 36.35 & 35.43 & 36.40 \\
\hline 23 & 24.74 & 24.91 & 24.77 & 24.94 \\
\hline 24 & 125.07 & 125.12 & 125.22 & 125.26 \\
\hline 25 & 131.04 & 131.01 & 130.08 & 130.90 \\
\hline 26 & 25.76 & 25.73 & 17.69 & 17.62 \\
\hline 27 & 17.71 & 17.65 & 25.74 & 25.71 \\
\hline 28 & 27.28 & 27.29 & 27.92 & 27.92 \\
\hline 29 & 15.07 & 15.07 & 15.53 & 15.43 \\
\hline 30 & 24.42 & 24.31 & 24.47 & 24.36 \\
\hline
\end{tabular}

Record in $\mathrm{CDCl}_{3}, 100 \mathrm{MHz}$ for ${ }^{13} \mathrm{C}, \delta$ in $\mathrm{ppm}, \mathrm{J}=\mathrm{Hz}$.

Supplementary Materials: Supplementary materials are available online.

Acknowledgments: The authors gratefully acknowledge the National Natural Science Foundation of China (81373972, 81673599 and 30973940), the National Basic Research Program of China (973 Program) (2011CB-505300 and 2011CB505303) for financially supporting this work. This research was also supported by a Project Funded by the Priority Academic Program Development of Jiangsu Higher Education Institutions (PAPD-2014), Six Talent Peaks Project in Jiangsu Province (2010-YY-026 and 2016-YY-009) and Innovative Project of College Students in Jiangsu Province (201610315023Z). In addition, this work was completed in Class III Laboratory of Chemistry of Chinese Materia Medica of State Administration of Traditional Chinese Medicine of China.

Author Contributions: Q.Z., Q.-R.Z., J.-W.L. and L.Z. participated in research design. Q.Z., P.-D.C., W.-F.Y. and W.-W.T. performed the experiments and analyzed data. Q.Z., K.W. and G.-C.D. wrote this manuscript. Y.-P.T. and L.Z. reviewed and edited this manuscript. All authors read and approved the final manuscript.

Conflicts of Interest: The authors declare no conflicts of interest.

\section{References}

1. Geng, T.; Huang, H.Y.; Ding, A.W.; Zhang, L. Irritation and diarrhea effect of different polar parts of Euphorbia kansui T. and vinegar-preparing Euphorbia kansui T. Cent. South Pharm. 2008, 6, 385-388.

2. Wang, L.; Ma, Y.T.; Sun, Q.Y.; Li, X.N.; Yan, Y.; Yang, J.; Yang, F.-M.; Liu, F.-Y.; Zang, Z.; Wu, X.H.; et al. Structurally diversified diterpenoids from Euphorbia dracunculoides. Tetrahedron 2015, 71, 5484-5493. [CrossRef]

3. Wang, H.; Wang, J.; Luo, J.; Kong, L. Isolation of ingenol-type diterpenoids from Euphorbia kansui by offline coupling of HPLC-ESI-MSn and HSCCC. Sep. Sci. Technol. 2013, 48, 1745-1751. [CrossRef]

4. Wang, L.Y. The Bioactive Study of Constituents in Kansui. Ph.D. Thesis, Shenyang Pharmaceutical University, Shenyang, China, 2003. 
5. Cheng, F.; Yang, Y.; Zhang, L.; Cao, Y.; Yao, W.; Tang, Y.; Ding, A. A natural triterpene derivative from Euphorbia kansui inhibits cell proliferation and induces apoptosis against rat intestinal epithelioid cell line in vitro. Int. J. Mol. Sci. 2015, 16, 18956-18975. [CrossRef] [PubMed]

6. Shi, Q.W.; Su, X.H.; Kiyota, H. Chemical and pharmacological research of the plants in genus Euphorbia. Chem. Rev. 2008, 108, 4295-4327. [CrossRef] [PubMed]

7. Zheng, W.F.; Cui, Z.; Zhu, Q. Cytotoxicity and antiviral activity of the compounds from Euphorbia kansui. Planta Med. 1998, 64, 754-756. [CrossRef] [PubMed]

8. Li, X.R.; Zhang, Y.D.; Tang, H.H. Study of auxiliary therapeutic effect of kansui root on patients with severe acute pancreatitis. China J. Mod. Med. 2002, 12,8.

9. Yan, X.; Zhang, L.; Guo, J.; Cao, Y.; Shang, E.; Tang, Y.; Ding, A.; Duan, J.A. Processing of kansui roots stir-baked with vinegar reduces kansui-induced hepatocyte cytotoxicity by decreasing the contents of toxic terpenoids and regulating the cell apoptosis pathway. Molecules 2014, 19, 7237-7254. [CrossRef] [PubMed]

10. Wang, L.Y.; Wang, N.L.; Yao, X.S.; Miyata, S.; Kitanaka, S. Euphane and tirucallane triterpenes from the roots of Euphorbia kansui and their in vitro effects on the cell division of Xenopus. J. Nat. Prod. 2003, 66, 630-633. [CrossRef] [PubMed]

11. Ahmed, E.; Malik, A.; Ferheen, S.; Afza, N.; Lodhi, M.A.; Choudhary, M.I. Chymotrypsin inhibitory triterpenoids from Silybum marianum. Chem. Pharm. Bull. 2006, 54, 103-106. [CrossRef] [PubMed]

12. Abe, I.; Rohmer, M. Enzymic cyclization of 2,3-dihydrosqualene and squalene 2,3-epoxide by squalene cyclases: From pentacyclic to tetracyclic triterpenes. J. Chem. Soc. Perkin Trans. 1 1994, 7, 783-791. [CrossRef]

13. Mishra, M.; Shukla, Y.N.; Kumar, S. Euphane triterpenoid and lipid constituents from Butea monosperma. Phytochemistry 2000, 54, 835-838. [CrossRef]

14. Wang, S.; Liang, H.; Zhao, Y.; Wang, G.; Yao, H.; Kasimu, R.; Wu, Z.; Li, Y.; Huang, J.; Wang, J. New triterpenoids from the latex of Euphorbia resinifera Berg. Fitoterapia 2016, 108, 33-40. [CrossRef] [PubMed]

15. Akihisa, T.; Yasukawa, K.; Kimura, Y.; Takase, S.I.; Yamanouchi, S.; Tamura, T. Triterpene alcohols from camellia and sasanqua oils and their anti-inflammatory effects. Chem. Pharm. Bull. 1997, 45, 2016-2023. [CrossRef] [PubMed]

16. Pan, D.-J.; Hu, C.-Q.; Chang, J.-J.; Lee, T.T.-Y.; Chen, Y.-P.; Hsu, H.-Y.; Mcphail, D.R.; Mcphail, A.T.; Lee, K.-H. Kansuiphorin-C and-D, cytotoxic diterpenes from Euphorbia kansui. Phytochemistry 1991, 30, 1018-1020.

17. Uemura, D.; Hirata, Y.; Chen, Y.P.; Hsu, H.Y. The structure of kansuinine A, a new multi-oxygenated diterpene. Tetrahedron Lett. 1975, 16, 1697-1700. [CrossRef]

18. Gewali, M.B.; Hattori, M.; Tezuka, Y.; Kikuchi, T.; Namba, T. Constituents of the latex of Euphorbia antiquorum. Phytochemistry 1990, 29, 1625-1628. [CrossRef]

19. Itoh, T.; Tamura, T.; Matsumoto, T. Tirucalla-7, 24-dienol: A new triterpene alcohol from tea seed oil. Lipids 1976, 11, 434-441. [CrossRef]

20. Gao, J.; Gao, L.; Zhang, L.; Yao, W.; Cao, Y.; Bao, B.; Ding, A. 3-O-(2'E,4'Z-decadienoyl)-20-O-acetylingenol induces apoptosis in intestinal epithelial cells of rats via mitochondrial pathway. J. Ethnopharmacol. 2015, 174, 331-338. [CrossRef] [PubMed]

21. Zhang, L.; Gao, L.; Li, Z.; Yan, X.; Yang, Y.; Tang, Y.; Cao, Y.; Ding, A. Bio-guided isolation of the cytotoxic terpenoids from the roots of Euphorbia kansui against human normal cell lines L-O2 and GES-1. Int. J. Mol. Sci. 2012, 13, 11247-11259. [CrossRef] [PubMed]

22. Shen, J.; Wang, J.; Shang, E.X.; Tang, Y.P.; Kai, J.; Cao, Y.J.; Zhou, G.S.; Tao, W.W.; Kang, A.; Su, S.L.; et al. The dosage-toxicity-efficacy relationship of kansui and licorice in malignant pleural effusion rats based on factor analysis. J. Ethnopharmacol. 2016, 186, 251-256. [CrossRef] [PubMed]

23. Yan, X.; Zhang, L.; Cao, Y.; Yao, W.; Tang, Y.; Ding, A. An Ingenol Derived from Euphorbia kansui Induces Hepatocyte Cytotoxicity by Triggering G0/G1 Cell Cycle Arrest and Regulating the Mitochondrial Apoptosis Pathway in Vitro. Molecules 2016, 21, 813. [CrossRef] [PubMed]

Sample Availability: Not available.

(C) 2017 by the authors. Licensee MDPI, Basel, Switzerland. This article is an open access article distributed under the terms and conditions of the Creative Commons Attribution (CC BY) license (http://creativecommons.org/licenses/by/4.0/). 